https://doi.org/10.30910/turkjans.680088

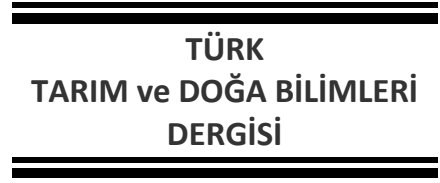

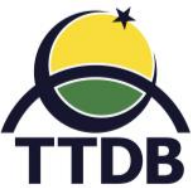

www.dergipark.gov.tr/turkjans

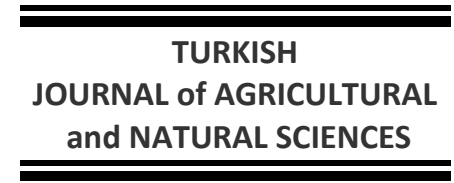

Araştırma Makalesi

\title{
Gaziantep İlindeki Tüketicilerin Yumurta Tüketim Alışkanlıklarının Belirlenmesi
}

\author{
Yeşim AYTOP*, Fikret IŞIK
}

Kahramanmaraş Sütçü İmam Üniversitesi, Ziraat Fakültesi, Tarım Ekonomisi Bölümü, Kahramanmaraş

*Sorumlu yazar: yesimmeral@ksu.edu.tr

Geliş Tarihi: 27.11.2019

Düzeltme Geliş Tarihi: 09.01.2020

Kabul Tarihi: 09.01.2020

Özet

Bu çalışmanın amacı Gaziantep ili kent merkezindeki tüketicilerin yumurta tüketim davranışlarını ve tüketim tercihinde etkili olan faktörleri belirlemektir. Araştırmanın ana materyalini Gaziantep ili kent merkezinde 271 tüketici ile yapılan anketlerden elde edilen veriler oluşturmaktadır. Verilerin analizinde tanımlayıcı istatistikler, F-testi ve ki-kare testlerinden yararlanılmıştır. Araştırma bulgularına göre, tüketicilerin \%96.31'inin yumurta tükettiği, hanede haftada ortalama 16.79 adet yumurta tüketildiği ve yumurta harcamasının aylık gıda harcaması içerisinde payının \%3.81 olduğu tespit edilmiştir. Tüketicilerin önemli bir kısmı (\%89.27) market veya süpermarketlerden yumurta satın alırken, \%42,50'si sadece markalı yumurta tercih ettiklerini belirtmişlerdir. Tüketiciler yumurtada dikkat edilen en önemli özelliklerin sırasıyla sağlıklı olması (4.87), imalat tarihi (4.85), tazeliği (4.84) ve tadı (4.81) olduğunu bildirmişlerdir. Yumurta tüketimi Türkiye ortalamasına yakın, ancak dünya ortalamasının oldukça altındadır ve artırılması gerekmektedir. Tüketici bilinçlendirme çalışmaları yapılması, hayvan ve çevre refahını artıracak önlemler alınması ve yumurtanın pazarlanabilirliğinin artırılması önerilmektedir.

Anahtar kelimeler: Yumurta, tüketici davranışları, Gaziantep.

\section{Determination of Egg Consumption Habits of Consumers in Gaziantep Province}

\begin{abstract}
The aim of this study is to determine the egg consumption behaviors of the consumers in Gaziantep and the factors affecting the consumption preferences. The main material of the study is the data obtained from surveys conducted with 271 consumers living in Gaziantep province. Descriptive statistics, $f$ and chi-square tests were used in the analysis of the data. According to the findings of the study, $96.31 \%$ of the consumers consume eggs, 16.79 eggs are consumed on average per week in the household and the rate of egg expenditure in the monthly food expenditure is $3.81 \%$. While a significant portion of consumers (89.27\%) purchased eggs from supermarkets, $42.50 \%$ of consumers preferred only branded eggs. Consumers reported that the most important characteristics observed in eggs were healthy (4.87), manufacturing date (4.85), freshness (4.84) and taste (4.81), respectively. Egg consumption is close to the average of Turkey, but well below the world average. It is recommended to increase the consumption of eggs, conduct consumer awareness studies, to take measures to increase animal and environmental welfare and to increase the marketability of eggs.
\end{abstract}

Key words: Egg, consumer behavior, Gaziantep.

\section{Giriş}

Yüksek besin öğesi içeriğine rağmen düşük kalorili olan yumurta, doğal ambalajı ile hiçbir şekilde hile yapılamayan, büyüme gelişme ve hastalıklardan korunmada önemli bir hayvansal üründür (Anonim, 2019a). İçerdiği $A, E, D, K$ ve $B$ grubu vitaminler, demir fosfor gibi mineraller ile yeterli ve dengeli beslenme açısından önemli bir 
ürün olan yumurta, en iyi protein kalitesine sahip hayvansal fonksiyonel bir gıdadır (Stadelman ve ark., 1988'den aktaran Açıkgöz ve Soycan Önenç, 2006). Yumurta, insan tarafından sentezlenemeyen ve mutlaka yiyeceklerle alınması gereken önemli aminoasitlerin tamamını veya çok önemli bir kısmını uygun oran ve miktarlarda içermektedir (Çelebi ve Karaca, 2006). Yumurtalar insanlık tarihi boyunca tüketilmiş olmasına rağmen henüz potansiyeli kavranamamıştır (lannotti ve ark., 2014).

Önemli hayvansal ürün olan yumurtanın; fiyatının ucuz olması, kolay ulaşılabilir olması, pratik bir şekilde hazırlaması, çeşitli şekillerde tüketilebilir olması ve uzmanların tüketimini önermesi gibi birçok faktör tüketiciler tarafından tercih edilmesini sağlamaktadır.

Dünya yumurta üretimi incelendiğinde ilk üç sırayı Çin (24.8 bin ton ), ABD (5.6 bin ton ) ve Hindistan (3.08 bin ton ) almaktadır. Türkiye 1.08 bin ton ile yumurta üretiminde sekizinci sırada yer almaktadır. Ülkemizin 2006 yılında 8.4 milyar adet olan ticari yumurta üretimi yıllar itibariyle artarak 2018 'de 22.3 milyar adete ulaşmıştır. Türkiye'nin 2018 yılı yumurta ihracatı bir önceki yıla göre \%15 artarak 430.7 milyon dolara ulaşmıştır. Bu ihracatın büyük bir kısmı Irak'a (\%71.1) ve Suudi Arabistan'a (\%9.1) yapılmaktadır. Yumurta ihracatının üretimdeki payının \%27.36 (Anonim, 2018a) olduğu düşünüldüğünde, üretilen yumurtanın yaklaşık \%20'si Irak'a ihraç edilmektedir. 2019 Mayıs ayında Irak'ın yumurta ithalatını yasaklaması (Anonim, 2019b) bu verilerde olumsuz değişikliklere neden olmuştur.

Kişi başına yıllık yumurta tüketim miktarı Japonya'da 333, Çin'de 307, Rusya'da 305, Arjantin'de 280 adet iken Türkiye'de 224 adettir (Anonim, 2018b).

2018 yılı verilerine göre ülkemizin toplam 127 milyon adet olan yumurtacı tavuk kümes kapasitesinin 25 milyonu Afyon, 20 milyonu Konya ve 11 milyonu Manisa ilinden karşılanmaktadır. Gaziantep 4 milyon ile, kümes kapasitesi sıralamasında ülkemizde onuncu sırada yer almaktadır (Anonim, 2018b).

Beslenme açısından oldukça önemli bir hayvansal ürün olan yumurta üretimi ve tüketimi konusunda dünyada ve Türkiye'de çeşitli çalışmalar yapılmıştır. Türkiye'deki yumurta tüketim miktarını ve tüketimde etkili olan faktörleri belirlemeye yönelik yapılan çalışmalardan bazıları aşağıda özetlenmiştir.

Çelik ve Şengül (2001) Şanlıurfa ilinde yaptıkları araştırmalarında, kişi başına yıllık yumurta tüketiminin 126 adet olduğunu ve tüketicilerin \%62.9'unun yumurta fiyatlarından etkilenmediğini, Armağan ve Özdoğan (2005) Aydın ilinde yaptıkları araştırmalarında kişi başı yıllık yumurta tüketim miktarını 228.8 adet olduğunu, Durmuş ve ark. (2007) yılında Ankara ilinde yaptıkları araştırmalarında kişi başına yıllık yumurta tüketiminin ortalama 171 adet olduğunu, yumurtanın büyük bir oranda marketlerden satın alındığı ve tercihte ambalajın etkili olduğunu tespit etmişlerdir. Mızrak (2011) Türkiye'de 2241 tüketici ile yaptığı araştırmasında, ailelerin \%98'inin yumurta tükettiğini ve yılda kişi başına yumurta tüketiminin ortalama 158 adet olduğunu ayrıca kuş gribi hastalığının yumurta tüketiminde \%36 oranında azalmaya yol açtığını bulmuşlardır. Karakaya ve ark. (2014) Bingöl ilinde yaptıkları araştırmalarında kişi başına yıllık yumurta tüketiminin 146.3 adet olduğunu ve tüketicilerin \%77.3'ünün yumurtayı marketten satın aldıklarını belirlemişlerdir. Bircan ve ark. (2017) Sivas ilinde yaptıkları araştırmalarında kişi başı yıllık yumurta tüketimini 123.40 adet, Eleroğlu ve ark. (2018) Yozgat ilinde yaptıkları araştırmalarında kişi başı yıllık yumurta tüketim miktarını 130.49 adet olarak bulmuşlardır.

Yapılan çalışmalar incelendiğinde, Gaziantep ili kent merkezinde yumurta tüketimini inceleyen bir çalışmanın olmadığı sonucuna ulaşılmıştır.

$\mathrm{Bu}$ araştırmanın amacı Gaziantep ili kent merkezindeki tüketicilerin yumurta tüketiminde etkili faktörleri belirleyerek tüketim tercihlerini ortaya koymaktır.

Temel amaç doğrultusunda daha ayrıntılı olarak; Gaziantep ili Merkez ilçedeki tüketicilerin sosyo-demografik özelliklerinin belirlenmesi, tüketicilerin yumurta tüketme durumları ve tüketme sıklıklarının belirlenmesi, yumurta tüketme ve tüketmeme nedenlerinin belirlenmesi, yumurtanın temin edildiği pazarlama kanallarının belirlenmesi ve yumurta satın alırken dikkat edilen özelliklerin belirlenmesi amaçlanmıştır.

$\mathrm{Bu}$ araştırmanın sonuçları yumurta tüketim davranışları ortaya koyduğu için konu ile ilgili araştırmacılara, firmalara, karar vericilere, üretici ve tüketicilere katkı sağlaması beklenmektedir.

\section{Materyal ve Yöntem}

Araştırmanın ana materyalini oransal örnekleme yöntemine göre belirlenmiş 271 tüketici ile yapılan anketlerden elde edilen veriler oluşturmaktadır. Anket çalışması, 2018 yılı OcakMart aylarında Gaziantep ili merkez ilçeleri olan Şahinbey ve Şehitkamil ilçelerinde gerçekleştirilmiştir.

Yapılacak anket sayısının belirlenmesinde oransal örnek hacmi formülü kullanılmıştır (Newbold, 2009).

$$
n=\frac{N p(1-p)}{(N-1) \sigma_{\hat{p}_{x}}^{2}+p(1-p)}
$$


$\boldsymbol{\sigma}_{\widehat{\boldsymbol{p}}_{x}}^{2}=$ Oranın varyansı, $\mathrm{n}$ : Örnek hacmi, $\mathrm{N}$ : Anakitle, p: Oran (maksimum örnek hacmine ulaşmak amacıyla $\mathrm{p}=0.5$ alınmıştır).

Tüik verilerine göre, Gaziantep ili kent merkezi nüfusu 1.663.273 kişidir (TÜiK, 2017). \%90 güven aralığı ve \%5 hata payı ile örnek sayısı 271 olarak bulunmuştur. Anketler ilçelerdeki kişi sayısı dikkate alınarak oransal olarak dağıtılmıştır. Anketlerin \%54'ü (146 anket) Şahinbey ilçesinde, \%46'sı (125 anket) Şehitkâmil ilçesinde yapılmıştır. Verilerin analizinde tanımlayıcı istatistikler ki-kare ve One-way ANOVA testi kullanılmıştır.

Çalışmanın ikincil verilerini, kurumların yayınlamış oldukları istatistiki veriler ve konu hakkında yapılmış diğer çalışmalara ait bilgiler oluşturmaktadır.

\section{Bulgular ve Tartışma}

Anket yapılan tüketicilerin sosyodemografik özelliklerine ait bilgiler Çizelge 1'de verilmiştir. Tüketicilerin büyük bir oranının $(\% 44,28)$ 31-45 yaş aralığında olduğu, ortalama yaşın 40,17 yıl, alınan eğitim süresinin ise ortalama 8,09 yıl olduğu tespit edilmiştir. Tüketicilerin \%53,51'inin erkek, \%82,66'sının evli, 38,38'inin özel sektör çalışanı ve serbest meslek erbabı olduğu belirlenmiştir. Tüketicilerin \%69'unun Gaziantepli olduğu ve ortalama 31,91 yıldır Gaziantep ilinde yaşadıkları belirlenmiştir. Tüketicilerin yaklaşık yarısının (\%51,66) 2000-3999 TL gelire sahip oldukları, hanehalkı ortalama gelirinin aylık ortalama $2730,44 \mathrm{TL}$ olduğu ve aylık gelirin ortalama \%25,71'ini gıda harcamasına (702,16 TL/ay) ayırdıkları tespit edilmiştir. Tüketicilerin \%44,28'inin hanehalkının 4-5 kişiden oluştuğu (hanede yaşayan birey sayısı ortalama:4,01 kişi), hanede çalışan birey sayısı ortalamasının 1,21 kişi, çocuk sayısının ise ortalama 2.37 kişi olduğu belirlenmiştir.

Çizelge 1. Anket yapılan tüketicilerin sosyo-demografik özellikleri

\begin{tabular}{|c|c|c|c|c|c|}
\hline Demografik özellikler & Kişi sayısı & Oran (\%) & Demografik özellikler & Kişi sayısı & Oran (\%) \\
\hline Yaş (yıl) & & & Gelir (TL/ay) & & \\
\hline$<30$ & 70 & 25.83 & $\leq 1999$ & 81 & 29.89 \\
\hline $31-45$ & 120 & 44.28 & 2000-3999 & 140 & 51.66 \\
\hline$\geq 46$ & 81 & 29.89 & $\geq 4000$ & 50 & 18.45 \\
\hline Toplam & 271 & 100.00 & Toplam & 271 & 100.00 \\
\hline Cinsiyet & & & Medeni durum & & \\
\hline Kadın & 126 & 46.49 & Bekar & 47 & 17.34 \\
\hline Erkek & 145 & 53.51 & Evli & 224 & 82.66 \\
\hline Toplam & 271 & 100.00 & Toplam & 271 & 100.00 \\
\hline Ailede çalışan sayısı & & & Memleket & & \\
\hline$\leq 1$ & 210 & 77.49 & Gaziantep & 187 & 69.00 \\
\hline 2 & 52 & 19.19 & Şanlıurfa & 16 & 5.90 \\
\hline$\geq 3$ & 9 & 3.32 & Kahramanmaraş & 14 & 5.17 \\
\hline Toplam & 271 & 100.00 & Diğer & 54 & 19.93 \\
\hline Eğitim durumu (yıl) & & & Toplam & 271 & 100.00 \\
\hline$\leq 5$ & 120 & 44.28 & Çocuk sayısı & & \\
\hline $6-8$ & 45 & 16.61 & $\leq 2$ & 153 & 56.46 \\
\hline $9-12$ & 59 & 21.77 & $3-4$ & 89 & 32.84 \\
\hline$\geq 13$ & 47 & 17.34 & $\geq 5$ & 29 & 10.70 \\
\hline Toplam & 271 & 100.00 & Toplam & 271 & 100.00 \\
\hline Meslek & & & Hanehalkı sayısı & & \\
\hline Kamu çalışanı & 31 & 11.44 & $\leq 3$ & 103 & 38.01 \\
\hline Özel sektör çalışanı & 52 & 19.19 & $4-5$ & 120 & 44.28 \\
\hline Emekli & 29 & 10.70 & $\geq 6$ & 48 & 17.71 \\
\hline Serbest meslek & 52 & 19.19 & Toplam & 271 & 100.00 \\
\hline $\begin{array}{l}\text { İşsiz } \\
\text { (evhanımı+çalışmayan) }\end{array}$ & 44 & 16.24 & & & \\
\hline Öğrenci & 13 & 4.80 & & & \\
\hline Çiftçi & 50 & 18.45 & & & \\
\hline Toplam & 271 & 100.00 & & & \\
\hline
\end{tabular}


Çizelge 2'de anket yapılan bireylerin yumurta tüketim bilgilerine yer verilmiştir. Tüketicilerin \%96.31'i tavuk yumurtası tükettiklerini bildirmişlerdir. Mızrak (2011) Türkiye'de 2241 tüketici ile yaptığı araştırmasında ailelerin \%98'inin yumurta tükettiğini tespit etmiştir.

Aylık hanehalkı yumurta tüketimi ortalama 71.96 adet iken kişi başı yıllık yumurta tüketimi ortalama 218.32 adet olarak bulunmuştur. Türkiye'de kişi başı yılık yumurta tüketim miktarı 224'tür (Anonim, 2018a). Bulunan sonuç Türkiye ortalamasına oldukça yakındır. Yıllık gıda harcaması içinde \%3.81'lik paya sahip olan yumurta tüketimi için ödenen aylık miktar 26.73 TL'dir. Gelir grupları ile yumurta tüketme durumu, tüketim miktarı ve ödenen fiyat arasında istatistiki açıdan anlamlı bir farkın olup olmadığını belirlemek amacıyla ki-kare ve $f$ testi yapılmıştır. Yapılan test sonuçlarına göre gelir grupları ile tüketme durumu ( $p>0.05)$, tüketim miktarı ( $p>0.05$ ) açısından istatistiki açıdan anlamlı bir fark olmadığı tespit edilmiştir. Araştırma sonuçlarına benzer şekilde, Parlakay ve ark. (2017) Uşak ilinde yaptıkları araştırmalarında gelir düzeylerine göre tüketilen yumurta miktarları arasında istatistiki açıdan anlamlı bir fark olmadığını tespit etmişlerdir.

Çizelge 2. Yumurta tüketim bilgisi

\begin{tabular}{lcccccc} 
& \multicolumn{2}{c}{ Tüketme durumu (\%) } & Tüketim miktarı & Harcama \\
\hline & Tüketmeyen & Tüketen & $\begin{array}{c}\text { Hanehalkı } \\
\text { adet/hafta }\end{array}$ & $\begin{array}{c}\text { Kişi Başı } \\
\text { adet/yı }\end{array}$ & $\begin{array}{c}\text { Harcama } \\
\text { değeri } \\
\text { TL/ay }\end{array}$ & $\begin{array}{c}\text { Aylık gıda } \\
\text { harcaması } \\
\text { içindeki payı \% }\end{array}$ \\
\hline Düşük gelir $\leq 1999 \mathrm{TL}$ & 3.70 & 96.30 & 16.30 & 211.95 & 25.95 & 3.70 \\
Ortagelir 2000-3999 TL & 2.14 & 97.86 & 17.76 & 230.94 & 28.27 & 4.03 \\
Yüksek gelir $\geq 4000 \mathrm{TL}$ & 8.00 & 92.00 & 14.88 & 193.49 & 23.69 & 3.37 \\
Genel & 3.69 & 96.31 & 16.79 & 218.32 & 26.73 & 3.81 \\
\hline Ki-kare (p değeri) & $3,556(0,169)$ & & & & \\
F (p değeri) & & & & & &
\end{tabular}

Ailedeki bireylerin yumurta tüketim sıklığına ilişkin bilgiler Çizelge 3'te verilmiştir. $\geq 15$ yaş çocukların \%10.95'inin, 7-14 yaş arasındaki çocukların ise \%8.80'inin yumurta tüketmedikleri tespit edilmiştir. Ailedeki bireylerin büyük bir kısmı her gün yumurta tüketmektedirler. Çocukların gelişimlerine önemli katkı sağlayan yumurtayı her gün tüketenlerin en çok 0-6 yaş grubundaki çocuklar (\%81.31) olduğu görülmektedir. Konya ilinde yapılan araştırmada 5-6 yaş arasındaki çocukların \%42.2'sinin her gün, \%28'inin gün aşırı yumurta tükettikleri \%2.7'sinin ise hiç yumurta tüketmedikleri (Oğuz, 2011), Ortaokuldaki öğrencilerle yapılan başka bir çalışmada, öğrencilerin \%80.9'unun bazen, \%5'inin her gün, \%14.1'inin ise yumurta tüketmedikleri tespit edilmiştir (Özdoğan, 2006).

Çizelge 3. Yumurta tüketim sıklığı

\begin{tabular}{|c|c|c|c|c|c|c|c|c|c|c|}
\hline & \multicolumn{2}{|c|}{ Anne } & \multicolumn{2}{|c|}{ Baba } & \multicolumn{2}{|c|}{ 0-6 yaş çocuk } & \multicolumn{2}{|c|}{ 7-14 yaş çocuk } & \multicolumn{2}{|c|}{$\geq 15$ yaş çocuk } \\
\hline & $\begin{array}{c}\text { Kişi } \\
\text { sayısı }\end{array}$ & $\begin{array}{c}\text { Oran } \\
\text { (\%) }\end{array}$ & $\begin{array}{c}\text { Kişi } \\
\text { sayısı }\end{array}$ & $\begin{array}{c}\text { Oran } \\
(\%)\end{array}$ & $\begin{array}{c}\text { Kişi } \\
\text { sayısı }\end{array}$ & $\begin{array}{c}\text { Oran } \\
(\%)\end{array}$ & $\begin{array}{c}\text { Kişi } \\
\text { sayısı }\end{array}$ & $\begin{array}{c}\text { Oran } \\
(\%)\end{array}$ & $\begin{array}{c}\text { Kişi } \\
\text { sayısı }\end{array}$ & $\begin{array}{c}\text { Oran } \\
(\%)\end{array}$ \\
\hline Tüketmeyen & 9 & 3.37 & 18 & 6.79 & 5 & 4.67 & 11 & 8.80 & 15 & 10.95 \\
\hline Her Gün & 181 & 67.79 & 152 & 57.36 & 87 & 81.31 & 94 & 75.20 & 89 & 64.96 \\
\hline Haftada Birkaç Kez & 66 & 24.72 & 75 & 28.30 & 10 & 9.35 & 20 & 16.00 & 32 & 23.36 \\
\hline Daha nadir & 11 & 4.12 & 20 & 7.55 & 5 & 4.67 & 0 & 0.00 & 1 & 0.73 \\
\hline Toplam & 267 & 100.00 & 265 & 100.00 & 107 & 100.00 & 125 & 100.00 & 137 & 100.00 \\
\hline
\end{tabular}


Tüketicilerin yumurta satın alırken tercih ettiği pazarlama kanalları incelendiğinde büyük bir kısmının yumurtayı market-süpermarketlerden (\%89.27) temin ettikleri, diğer önemli bir kısmının ise bakkalları (\%34.10) tercih ettikleri görülmektedir. Direkt üretici (\%14.56), kasapşarküteri (\%19.16) ve pazarlardan (\%14.90) yumurta satın alan tüketici sayısı birbirine çok yakındır (Çizelge 4). Çelik ve Şengül (2001) Şanlıurfa ilinde yaptıkları araştırmalarında tüketicilerin \%45'inin marketten, \%19.2'sinin bakkaldan, \%13.1'inin semt pazarından, \%9.6'sının yumurta toptancısından ve \%13.1'inin uygun olan herhangi bir yerden yumurta satın aldıklarını tespit etmişlerdir. Durmuş ve ark. (2007) Ankara ilinde yaptıkları araştırmalarında kişi yumurtanın büyük bir oranda marketlerden satın alındığını, Karakaya ve ark. (2014) Bingöl ilinde yaptıkları araştırmalarında tüketicilerin \%77.3'ünün yumurtayı marketten satın aldıklarını tespit etmişlerdir.

Tüketicilerin çeşitli pazarlama kanallarından yumurta temin şekilleri Çizelge 4'te verilmişti. Yapılan anketlerde tüketicilerin ambalajsız ve markasız yumurtaları, köy yumurtası olarak değerlendirdikleri belirlenmiştir. Tüketiciler, köy yumurtalarının önemli bir kısmını direkt üreticiden ve pazarlardan temin etmektedir. Yine tüketiciler bakkallardan, kasaplardan ve az oranda da olsa marketlerden markası olmayan köy yumurtalarını bulabilmekte ve diğerlerine göre daha yüksek fiyat ödemektedirler.

Çizelge 4. Yumurta satın alım yeri

\begin{tabular}{lcc}
\hline & Kişi sayısı & Oran(\%) \\
\hline Direkt üretici & 38 & 14.56 \\
Kasap- şarküteri & 50 & 19.16 \\
Market -süpermarket & 233 & 89.27 \\
Bakkal & 89 & 34.10 \\
Pazar & 39 & 14.90 \\
\hline
\end{tabular}

Çizelge 5. Yumurtada marka tercih etme durumu

\begin{tabular}{lcc}
\hline & Kişi sayısı & Oran(\%) \\
\hline Yalnızca markalı & 111 & 42.53 \\
Yalnızca markasız & 5 & 1.87 \\
Hem markalı hem markasız & & 55.60 \\
\hline Toplam & 145 & 100.00
\end{tabular}

Tüketicilerin önemli bir kısmı (\%42.53) yumurta satın alırken yalnızca markalı olanları tercih ettiklerini, diğer önemli bir kısmı ise hem markalı hem de markasız yumurta (\%55.60) tercih ettiklerini bildirmişlerdir (Çizelge 5).

Tüketiciler gıda ürünlerini satın alırken bazı özelliklere dikkat etmektedirler. Tüketiciler yaptıkları alışverişleri, tekrar satın alımda deneyim olarak değerlendirmekte ve tüketim davranışlarını deneyimlerine göre gerçekleştirmektedirler. Bu bağlamda tüketicilerin yumurta satın alırken ve tüketirken dikkat ettikleri özelliklere önem verme dereceleri değerlendirilmiştir (Çizelge 6). Yumurtada dikkat edilen en önemli özellikler sırasıyla sağlıklı olması (4.87), üretim tarihi (4.85), tazeliği (4.84) ve tadıdır (4.81). En az dikkat edilen özelikler ise kabuk rengi (3.06), ağırlığı (2.95) ve ürünün üretildiği şehirdir (2.13). Araştırma sonuçlarına benzer şekilde Çelik ve Şengül (2001) Şanlıurfa ilinde yaptıkları araştırmalarında, tüketicilerin \%62.9'unun yumurta fiyatlarından etkilenmediğini, \%11.2'sinin ise yumurta rengini önemsemediklerini tespit etmişlerdir. Durmuş ve ark. (2007) Ankara ilinde yaptıkları araştırmalarında yumurta satın alırken tüketicilerin \%47.13'ünün üretim tarihine, $\% 14.65^{\prime}$ inin üretici firmaya, \%7.64'ünün fiyata dikkat ettiklerini tespit etmişlerdir. 
Çizelge 6. Yumurtada dikkat edilen özellikler

\begin{tabular}{lcc}
\hline Özellik & Ortalama & Std. Sapma \\
\hline Sağlıklı olması & 4.87 & 0.433 \\
Üretim tarihi & 4.85 & 0.486 \\
Tazelik & 4.84 & 0.528 \\
Tadı & 4.81 & 0.438 \\
Kalitesi & 4.78 & 0.506 \\
Kokusu & 4.75 & 0.618 \\
Görünüşü & 4.48 & 0.991 \\
Kalite belgeleri & 4.48 & 0.967 \\
Organik olması & 4.15 & 1.162 \\
Markası & 4.11 & 1.153 \\
Uzmanların önermesi & 3.71 & 1.457 \\
Ürüne ilişkin daha önceki deneyimler & 3.70 & 1.492 \\
Fiyatı & 3.62 & 1.546 \\
Alındığı kişi ya da satış mağazası & 3.62 & 1.503 \\
Gezen tavuk yumurtası olması & 3.59 & 1.595 \\
Aileden gelen alışkanlık & 3.49 & 1.684 \\
Kabuk rengi & 3.06 & 1.617 \\
Büyüklüğü & 2.95 & 1.698 \\
Ürünün ait olduğu şehir & 2.13 & 1.481 \\
\hline
\end{tabular}

Önemsiz: 1, Çok az önemli: 2, Orta önemli: 3, Oldukça önemli: 4, Çok önemli: 5.

\section{Sonuç ve Öneriler}

$\mathrm{Bu}$ çalışma Gaziantep kent merkezindeki tüketicilerin yumurta tüketim davranışlarını ortaya koymak amacıyla yapılmıştır.

Yumurta kahvaltılarda, yemeklerde, pastalarda, böreklerde vb. direkt veya dolaylı olarak kullanılmaktadır. Araştırma alanında yıllık kişi başı yumurta tüketimi Türkiye ortalamasına çok yakın çıkmıştır. Ancak sağlık açısından önemi bir gıda ürünü olan yumurtanın Gaziantep ilindeki tüketimi dünya ortalamasının oldukça altındadır. $\mathrm{Bu}$ açıdan çeşitli şekillerde yumurta tüketiminin artırılması gerekmektedir. TV/radyo/internet vasıtası ile yumurtanın yararları hakkında yapılacak programlar geniş kitlelere ulaşabilir ve tüketime katkı sağlayabilir. Bunun yanı sıra özellikle çocukların yumurta tüketimini artırmak için yapılacak bilinçlendirme çalışmaları, seminerler, okul kantinlerinde haşlanmış yumurta satışı gibi birçok uygulama yumurta tüketimini olumlu yönde etkileyebilir.

Tüketiciler yumurta satın alırken imalat tarihi, marka, kalite belgeleri gibi birçok özelliğe dikkat etmektedir. Yumurtanın doğal ambalajında hile yapılması mümkün değildir. Tüketiciler yumurtanın kullanım süresinin, üretim tarihinden itibaren 28 gün olduğuna dikkat ederek, üzerindeki kodları silinmemiş, temiz ve çatlak olmayan yumurtaları tercih etmeliler. Yumurtalar; gezen tavuk yumurtası, organik yumurta, çiftlik yumurtası, köy yumurtası gibi çeşitli şekillerde adlandırılmaktadır. Yapılan çalışmalarda tüketicilerin çiftlik yumurtası haricindeki diğer yumurtalara daha fazla ödeme isteğinde bulundukları tespit edilmiştir. Ancak tüketiciler bu yumurtalar arasında ne gibi fark olduğunu bilmemektedir. Besin içeriği yönünden gerçekten bu yumurtalar arasında bir farkın olup olmadığı tüketicilere detaylı bir şekilde anlatılıp, tüketici istismarı önlenmelidir.

Yumurta tavukçuluğunda hayvan ve çevre refahını artıracak önlemler alınmasının sektöre katkı sağlayacağı düşünülmektedir. Yumurta sektörünün devamlılı̆ının sağlanması açısından alınacak biyogüvenlik önlemleri ile tavuklar arasında bulaşıcı hastalıklarının yayılmasının engellenmesi amaçlanmalıdır.

Yumurtanın pazarlanmasıyla ilgili sorunların temelinde kısa raf ömrü gelmektedir. Bu durumda sektör, talep dalgalanmalarından oldukça olumsuz etkilenmektedir. İşlenmiş yumurta ürünleri teknolojilerinin ve pazarlarının geliştirilmesi sürdürülebilirlik açısından önem arz etmektedir.

\section{Kaynakça}

Açıkgöz, Z., Soycan Önenç, S. 2006. Fonksiyonel Yumurta Üretimi, Hayvansal Üretim, 47(1): 36-46.

Anonim, 2018a. Yumurta Haber Bülteni. (https://view.publitas.com) (Erişim tarihi: 24.04.2019).

Anonim, 2018b. Yum-Bir Yumurta Tavukçuluğu Verileri. (https://www.yum-bir.org) (Erişim tarihi: 24.04.2019).

Anonim, 2019a. Yumurta Hakkında. (https://www.yum-bir.org) (Erişim tarihi: 10.06.2019). 
Anonim, 2019b. Yumurta Haber Bülteni. (https://view.publitas.com) (Erişim tarihi: 17.10.2019).

Armağan, G., Özdoğan, M. 2005. Ekolojik Yumurta ve Tavuk Etinin Tüketim Eğilimleri ve Tüketici Özelliklerinin Belirlenmesi. Hayvansal Üretim, 46(2): 14-21.

Bircan, H., Eleroğlu, H., Arslan, R. 2017. Sivas Kent Merkezinde Tavukçuluk Ürünlerinin Tüketimi ve Tüketime Etki Eden Faktörler, Türk Tarım - Gıda Bilim ve Teknoloji Dergisi, 5(12): 1609-1614.

Çelebi, Ş., Karaca, H. 2006. Yumurtanın Besin Değeri, Kolesterol İçeriği Ve Yumurtayı n-3 Yağ Asitleri Bakımından Zenginleştirmeye Yönelik Çalışmalar. Atatürk Üniversitesi Ziraat Fakültesi Dergisi, 37(2): 257-265.

Çelik, Y., Şengül, T. 2001. Şanlıurfa İli Kentsel Alanında Tüketicilerin Yumurta Tüketim Düzeyleri ve Tüketim Alışkanlıklarının Belirlenmesi, Hayvansal Üretim, 42 (2): 5362.

Durmuş, I., Demirtaş, Ş.E., Can, M., Kalebaşı, S. 2007. Ankara ilinde Yumurta Tüketim Alışkanlığının Belirlenmesi, Tavukçuluk Araştırma Dergisi, 7 (1): 42-45.

Eleroğlu, H , Bircan, H., Arslan, R., 2018. Yozgat il Merkezinde Yumurta ve Tavuk Eti Tüketimi Üzerine Etki Eden Faktörler, Tavukçuluk Araştırma Dergisi, 15 (1): 29-33.

Iannottı, L.L.; Lutter, C.K.; Bunn, D.A.; Stewart, C.P. 2014. Eggs: The Uncracked Potential for Improving Maternal and Young Child Nutrition among the World's Poor. Nutrition Reviews, 72: 355-368.

Karakaya, E., İnci, H., Söğüt, B., Şengül, T. 2014. Bingöl il Merkezinde Yaşayan Hane Halklarının Yumurta Tüketim Durumu Üzerine Bir Araştırma, Türk Tarım ve Doğa Bilimleri Dergisi, 1(2): 239-247.

Mızrak, C. 2011. Türkiye'de Yumurta ve Tavuk Eti Tüketim Alışkanlıklarının Belirlenmesi, T.C. Gıda, Tarım ve Hayvancılık Bakanlığı, Tavukçuluk Araştırma İstasyonu Müdürlüğü, Araştırma Projesi, Ankara. (http://www.tae.gov.tr) (Erişim tarihi: 17.05.2019).

Newbold, P., 2009. İşletme ve İktisat İçin İstatistik, (Çev. Ümit Şenesen), İstanbul, Literatür Yayınları.

Oğuz, ş. 2011. Konya II Merkezinde Okulöncesi Eğitim Kurumlarına Devam Etmekte Olan 60-72 Aylık Çocukların Beslenme Alışkanlıkları, Selçuk Üniversitesi Eğitim Bilimleri Enstitüsü, Yayınlanmamış Yüksek Lisans Tezi, Konya, 304s.
Özdoğan, Y. 2006. Konya II Merkezinde Farklı Sosyo Ekonomik Düzeylerdeki İlköğretim Okullarına Devam Eden Çocukların Kahvaltı Yapma Alışkanlıklarının Saptanması, Selçuk Üniversitesi, Sosyal Bilimler Enstitüsü, Yayınlanmamış Yüksek Lisans Tezi, Konya, $148 \mathrm{~s}$.

Parlakay, O., Arslan, A., Akın, Y. 2017. Tüketicilerin Yumurta Tüketim Tercihlerinin Belirlenmesi: Uşak İli Örneği, Gaziosmanpaşa Üniversitesi Ziraat Fakültesi Dergisi, 34 (2): 108-115.

Stadelman, W.J., Olson, V. M., Shemwell, G. A., Pasch, S. 1988. Egg and Meat Processing. Ellis Horword Ltd. Chichester (England) s, 211.

TÜik, 2017. Adrese Dayalı Nüfus Kayıt Sistemi, (http://www.tuik.gov.tr) (Erişim tarihi: 23.07.2019). 